\title{
trans-Arylplatinum(II) Methyl Compounds Containing a Bis(imino)aryl [NCN] Ligand
}

\author{
Wilhelmus J . Hoogervorst, ${ }^{\dagger}$ Anne L. Koster, ${ }^{\dagger}$ Martin Lutz, ${ }^{\ddagger}$ \\ Anthony L. Spek, ${ }^{\ddagger}$ and Cornelis J . Elsevier*, ${ }^{\dagger}$ \\ Institute of Molecular Chemistry, Universiteit van Amsterdam, Nieuwe Achtergracht 166, \\ NL-1018 WV Amsterdam, The Netherlands, and Bijvoet Center for Biomolecular Research, \\ Vakgroep Kristal- en Struktuurchemie, Utrecht University, \\ Padualaan 8, NL-3584 CH Utrecht, The Netherlands
}

Received December 22, 2003

Summary: The synthesis and the first X-ray crystal structure of stabletrans-aryl platinum methyl complexes $\left[\mathrm{Pt}\left(\mathrm{CH}_{3}\right) \mathrm{NCN}\right]$ with imine type $\mathrm{N}$ ligands are reported. These are interesting examples of compounds on the reaction coordinate of $\mathrm{C}-\mathrm{C}$ bond-forming and bondbreaking reactions, which have so far not been observed in the known series of $\mathrm{Pt}(\mathrm{II})$ complexes featuring an amine type $\mathrm{N}-\mathrm{C}-\mathrm{N}$ "pincer" ligand. Due to the strong $C\left(\mathrm{sp}^{2}\right)-\mathrm{C}\left(\mathrm{sp}^{3}\right)$ bond, only very few transition-metal compounds having an aryl as well as a methyl group bonded to the same metal atom areknown and, usually, reductive elimination occurs. In case of the title compounds, this is prevented dueto the trans disposition of themethyl and aryl groups and the rigid coplanarity of the chelate rings. This prevents deformation of the $\mathrm{N}-\mathrm{C}-\mathrm{N}$ tridentate ligand in the coordination plane.

Geometric isomers of the square-planar diorganoplatinum(II) compounds $P t_{2} L_{2}$ are relevant to mechanistic considerations concerning $\mathrm{C}-\mathrm{C}$ bond formation ${ }^{1-4}$ and to fundamental structural investigations. The strong trans influence exerted by hydrocarbyl ligands will bias the geometry of tetracoordinate diorganoplatinum(II) compounds toward cis complexes when $L$ is a monodentate or $L_{2}$ is a bidentate ancillary ligand, and even when $R L_{2}$ is a tridentate ligand, unless chelate effects are overriding. ${ }^{5-7}$ Much fewer examples are known of trans diorganoplatinum(II) compounds. Some of these platinum compounds have two monodentate phosphine ligands, ${ }^{8-11}$ in which case isomerization to the thermodynamically more stable cis-diorganoplatinum(II) diphosphine compounds may occur. ${ }^{12}$ In most

\footnotetext{
* To whom correspondence should be addressed. E-mail: elsevier@ science.uva.nl.

+ Universiteit van Amsterdam.

₹ Utrecht University.

(1) Low, J . J .; Goddard, W. A., III. J . Am. Chem. Soc. 1986, 108, $6115-6128$

(2) Hill, G. S.; Puddephatt, R. J . Organometallics 1998, 17, 1478 1486.

(3) Albrecht, M.; Spek, A. L.; van Koten, G. J . Am. Chem. Soc. 2001, $123,7233-7246$

(4) van der Boom, M. E.; Milstein, D. Chem. Rev. 2003, 103, 1759 1792.

(5) Clark, H. C.; von Werner, K. J . Organomet. Chem. 1975, 101, 347-358.

(6) Anderson, C.; Crespo, M.; J ennings, M. C.; Lough, A. J .; Ferguson, G.; Puddephatt, R. J . Organometallics 1991, 10, 2672-2679.

(7) Crespo, M.; Martinez, M.; Sales, J .; Solans, X.; F ont-Bardia, M. Organometallics 1992, 11, 1288-1295.

(8) Parshall, G. W. J . Am. Chem. Soc. 1966, 88, 704-708.

(9) Coulson, D. R. J . Am. Chem. Soc. 1976, 98, 3111-3119.

(10) Romeo, R.; Minniti, D.; Lanza, S. J . Organomet. Chem. 1979,
} 165, C36-38. 410.

(11) Hackett, M.; Whitesides, G. M. Organometallics 1987, 6, 403-

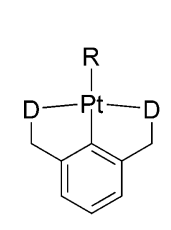

A

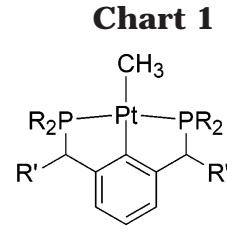

$B, R^{\prime}=H$

$B^{\prime}, R^{\prime}=M e$

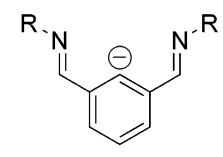

C of the other known trans-diorganoplatinum(II) compounds the remaining two (neutral) ligands bound to the platinum are forced into a trans configuration by using a meridionally coordinating and covalently bound [D-C-D] ligand (A; Chart 1).

Since the first report of a platinum(II) $[\mathrm{P}-\mathrm{C}-\mathrm{P}]$ compound, ${ }^{13}$ many papers concerning platinum(II) [D-C-D] compounds, bearing different donor groups, have appeared; the forced trans coordinating mode of the donor groups has resulted in trans-diorganoplatinum(II) compounds which contain $[\mathrm{P}-\mathrm{C}-\mathrm{P}]^{14-16}$ and $[\mathrm{N}-\mathrm{C}-\mathrm{N}]^{17-19}$ ligands.

When platinum(II) methyl compounds containing a [D-C-D] ligand are considered, it appears that only two examples of trans isomers have been documented; these are the platinum $[\mathrm{P}-\mathrm{C}-\mathrm{P}]$ methyl compounds $\mathbf{B}$ and $\mathbf{B}^{\prime}$ (Chart 1; R = Ph). ${ }^{14,16}$ However, none has been authenticated by means of a crystal structure determination. To the best of our knowledge, no trans-aryl platinum(II) methyl compound has ever been crystallographically authenticated. Only one crystal structure of a trans aryl-Pt-C $\left(\mathrm{sp}^{3}\right)$ compound has appeared at all; in this di phenyl phosphine-substituted $[\mathrm{P}-\mathrm{C}-\mathrm{P}]$ platinum compound, ${ }^{16}$ a $\sigma$-bonded $\mathrm{n}-\mathrm{C}_{3} \mathrm{~F}_{7}$ group is coordinated to platinum trans to the aryl carbon; i.e., electronic stabilization has been gained by introducing a perfluoroalkyl moiety.

(12) J awad, J . K.; Puddephatt, R. J .; Stalteri, M. A. Inorg. Chem 1982, 21, 332-337.

(13) Moulton, C. J .; Shaw, B. L. J . Chem. Soc., Dalton Trans. 1976 1020-1024.

(14) Gorla, F.; Venanzi, L. M.; Albinati, A. Organometallics 1994, $13,43-54$.

(15) Albrecht, M.; Dani, P.; Lutz, M.; Spek, A. L.; van Koten, G. J . Am. Chem. Soc. 2000, 122, 11822-11833.

(16) Hughes, R. P.; Williamson, A.; Incarvito, C. D.; Rheingold, A. L. Organometallics 2001, 20, 4741-4744.

(17) van Koten, G.; Terheijden, J .; van Beek, J . A. M.; WehmanOoyevaar, I. C. M.; Muller, F.; Stam, C. H. Organometallics 1990, 9, 903-912.

(18) Back, S.; Albrecht, M.; Spek, A. L.; Rheinwald, G.; Lang, H . van Koten, G. Organometallics 2001, 20, 1024-1027.

(19) Albrecht, M.; J ames, S. L.; Veldman, N.; Spek, A. L.; van Koten, G. Can. J . Chem. 2001, 79, 709. 
Scheme 1. Synthesis of Title Compounds

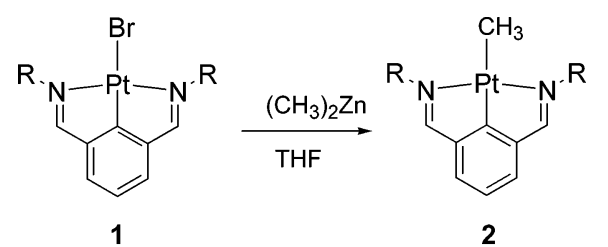
2

1a, 2a; $\mathrm{R}=2,6-(\mathrm{Pr})_{2}-\mathrm{C}_{6} \mathrm{H}_{3}$ 1b, 2b; $\mathrm{R}=2,6-(\mathrm{Me})_{2}-\mathrm{C}_{6} \mathrm{H}_{3}$ 1c; $\mathrm{R}=4-\mathrm{MeO}^{-\mathrm{C}_{6}} \mathrm{H}_{4}$

\section{Chart 2}

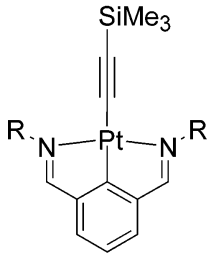

3

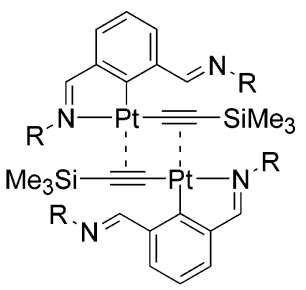

4
We now report the synthesis of thermally stable, novel trans-bis(imino)arylplatinum(II) methyl compounds 2 and the crystal structure of one of these, which were readily accessible from the corresponding platinum(II) hali de compounds 1 (see Scheme 1 ) by transmetalation.

The bis(imino)arylplatinum(II) bromide compounds la,c were described in our recent paper on acetylide derivatives $\mathbf{3}$ and $\mathbf{4}$ (see Chart 2);20 $\mathbf{1 b}$ was prepared similarly.

Synthesis of the thermally stable methyl derivatives 2 was attempted first by transmetalation of the respective bis(imino)aryl platinum(II) bromide compounds la-c with methyllithium, an approach which has been successful in the case of $[\mathrm{P}-\mathrm{C}-\mathrm{P}]$ ligands. ${ }^{14,16}$ However, when compounds $\mathbf{l a}, \mathbf{c}$ were reacted with methyllithium at low temperature in THF, the orange reaction mixture immediately turned green. $\mathrm{No} \mathrm{Pt}-\mathrm{CH}_{3}$ resonance was observed in the ${ }^{1} \mathrm{H}$ NMR spectra of the reaction mixtures. Probably, only undesired reactions such as electron transfer, proton abstraction, and addition to the imine moiety had occurred. Next, dimethylzinc was applied as a less basic and less nucleophilic methyl transfer reagent. Indeed, the transmetalation of $\mathbf{l a}$ was successfully performed (Scheme 1 ) at room temperature in THF by addition of excess dimethylzinc, upon which the color of the light orange reaction mixture slowly turned to dark red. ${ }^{1} \mathrm{H}$ NMR spectroscopic analysis pointed to the clean formation of a new methylplatinum compound (a correctly integrated $\mathrm{Pt}-\mathrm{CH}_{3}$ resonance at $\left.0.7 \mathrm{ppm},{ }^{3} \mathrm{~J}\left({ }^{1} \mathrm{H},{ }^{195} \mathrm{Pt}\right)=53 \mathrm{~Hz}, \mathrm{C}_{6} \mathrm{D}_{6}\right)$ which has structural features similar to those of $\mathbf{1 a}$. Pure $\mathbf{2 a}$ was isolated as red prisms in $95 \%$ yield. Similarly treating compound $\mathbf{1 b}$ with an excess of dimethylzinc at room temperature afforded the analogous bis(imino)aryl platinum(II) methyl compound $\mathbf{2} \mathbf{b}$ in $80 \%$ isolated yield.

It appeared that such bis(imino)arylplatinum(II) methyl compounds could be isolated only for sterically demanding aryl substituents on the imine moieties; for compound 1c ( $\mathrm{R}=4$-methoxyphenyl) the platinum(II) methyl compound $\mathbf{2 c}$ was observed by ${ }^{1} \mathrm{H}$ NMR in a

(20) Hoogervorst, W. J ; Elsevier, C. J ; Lutz, M.; Spek, A. L. Organometallics 2001, 20, 4437-4440.

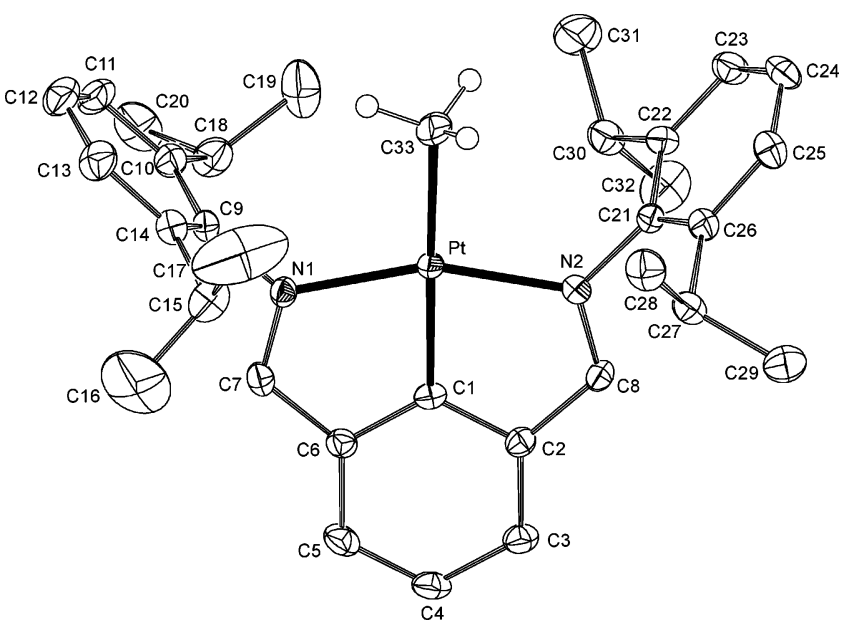

Figure 1. Displacement ellipsoid plot of $\mathbf{2 a}$, drawn at the $50 \%$ probability level. All hydrogen atoms except those of the methyl group have been omitted for clarity. Selected distances $(\AA)$, angles (deg), and torsion angles (deg): Pt$\mathrm{N} 1=2.045(2), \mathrm{Pt}-\mathrm{N} 2=2.036(2), \mathrm{Pt}-\mathrm{Cl}=1.944(2), \mathrm{Pt}-$ $\mathrm{C} 33=2.156(3), \mathrm{N} 1-\mathrm{C} 7=1.314(3), \mathrm{N} 1-\mathrm{C} 9=1.442(3)$, $\mathrm{N} 2-\mathrm{C} 8=1.304(3), \mathrm{N} 2-\mathrm{C} 21=1.439(3) ; \mathrm{N} 1-\mathrm{Pt}-\mathrm{N} 2=$ 157.63(8), N1-Pt-C1 = 78.93(9), N1-Pt-C33=102.22(10), $\mathrm{C} 1-\mathrm{Pt}-\mathrm{C} 33=173.49(12), \mathrm{N} 2-\mathrm{Pt}-\mathrm{C} 1=78.80(9), \mathrm{N} 2-\mathrm{Pt}-$ $\mathrm{C} 33=100.15(10), \mathrm{C} 7-\mathrm{N} 1-\mathrm{C} 9=118.9(2), \mathrm{C} 8-\mathrm{N} 2-\mathrm{C} 21=$ 120.7(2); $\mathrm{Pt}-\mathrm{C} 1-\mathrm{C} 2-\mathrm{C} 8=-5.2(3), \mathrm{Pt}-\mathrm{C} 1-\mathrm{C} 6-\mathrm{C} 7=$ 4.2(3).

sample of the reaction mixture, but it readily decomposed and could not be isolated.

The ${ }^{3}\left({ }^{1} \mathrm{H},{ }^{195} \mathrm{Pt}\right)$ values of the imine protons of $\mathbf{2} \mathbf{a}, \mathbf{b}$ $(125 \mathrm{~Hz})$ are substantially lower than those of $\mathbf{1 a , b}$ (144 $\mathrm{Hz}$ ) due to the larger cis influence of the methyl group compared to the bromide. In agreement with the nephelauxetic effect previously discussed, ${ }^{21}$ the ${ }^{195} \mathrm{Pt}$ chemical shift increases from $-3563 \mathrm{ppm}$ in $\mathbf{1 a}(-3517 \mathrm{ppm}$ in 1b) to $-3096 \mathrm{ppm}$ in $\mathbf{2 a}(-3074 \mathrm{ppm}$ in $\mathbf{2 b})$.

A single-crystal $X$-ray structure determination of $\mathbf{2 a}$ provided proof of its molecular structure, which is depicted in Figure 1; it constitutes the first crystal structure of a mononuclear trans-aryl platinum methyl compound. The molecular structure of $\mathbf{2 a}$ reveals bond lengths and angles that are similar to those in the acetylide 3: ${ }^{20}$ notably the lengths of their $\mathrm{Pt}-\mathrm{N}$ bonds and the Pt $-\mathrm{C}_{\text {aryl }}$ bond. The platinum has a distortedsquare-planar environment with a sum of cis angles of $360.1^{\circ}$. The short imine $\mathrm{C}=\mathrm{N}$ bonds lead to a large deviation from linearity of the trans $\mathrm{N}-\mathrm{Pt}-\mathrm{N}$ angle, amounting to $157.63(89)^{\circ}$ in $\mathbf{2 a}$, which is similar to that in $3\left(157.21(9)^{\circ}\right)$.

The Pt $-\mathrm{C}_{\text {methyl }}$ bond is relatively long (2.156(3) $\AA$ ), in agreement with the large mutual trans influence of the aryl and methyl groups, and is significantly longer than in compounds with, for example, $\mathrm{N}$ ligands in trans positions and/or with cis hydrocarbyl groups. ${ }^{22-25} \mathrm{How}$ ever, similar values have been reported for platinum methyl complexes with a trans phosphine ligand. ${ }^{26,27} \mathrm{~A}$ large trans influence has also been observed in the crystal structure of the trans-aryl platinum $\mathrm{C}_{3} \mathrm{~F}_{7}$ compound, ${ }_{1}^{16}$ where the $\mathrm{Pt}-\mathrm{CF}_{2} \mathrm{R}$ bond length is $2.186(8) \AA$. The five and six-membered rings in the coordination plane of platinum are almost planar; for the Pt(1), N(1), $C(1), C(6), C(7)$ plane, the largest deviation is $0.026(2)$

(21) Pregosin, P. S. Coord. Chem. Rev. 1982, 44, 247-291. 


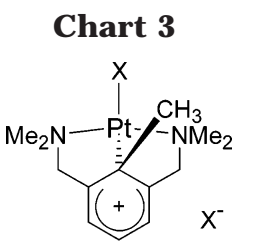

D

$\AA$, for the $\mathrm{Pt}(1), \mathrm{N}(1), \mathrm{C}(1), \mathrm{C}(2), \mathrm{C}(8)$ plane this is 0.034 (2) $\AA$, and for the aryl ring the largest deviation from planarity is $0.009(2) \AA$. These three planes are almost coplanar, the angles between these rings varying from $0.71(10)$ to $2.97(11)^{\circ}$.

In compounds $\mathbf{2 a} \mathbf{a} \mathbf{b}$ the trans disposition of the aryl and the methyl groups is dictated by the strong coordination of the chelating imine moieties. Possibly, the relative stability of $\mathbf{2} \mathbf{a}, \mathbf{b}$ can be ascribed to the rigidity of the fused five-membered-ring systems, which, due to the imine moieties, must remain essentially coplanar, allowing only small deviations from planarity.

Furthermore, since compound $\mathbf{2 c}$ could not be isolated, the presence of large ortho substituents on the $\mathrm{N}$-aryl ring probably also plays a role in preventing decomposition.

For related amine type $\mathrm{N}-\mathrm{C}-\mathrm{N}$ ("pincer") compounds, arylplatinum(II) methyl derivatives have been neither observed nor isolated. Instead, Pt(II)-arenium compounds of type $\mathbf{D}$ (see Chart 3) have been isolated, which arise via oxidative addition of methyl halide to a $\mathrm{Pt}(\mathrm{II})$ precursor, followed by a 1,2-methyl shift from the resulting $\mathrm{Pt}(\mathrm{IV})$ to the ipso carbon of the arene ring. ${ }^{28-30}$ F or phosphine type $\mathrm{P}-\mathrm{C}-\mathrm{P}$ compounds, a few arylmetal methyl compounds have been isolated, notably for Rh, but these are cis high-valent $d^{6}$ complexes. ${ }^{4,31}$

In conclusion, compounds $\mathbf{2} \mathbf{a}, \mathbf{b}$ constitute interesting examples of compounds on the reaction coordinate of $\mathrm{C}-\mathrm{C}$ bond-forming and bond-breaking reactions, which have so far not been observed in the known series of $\mathrm{Pt}(\mathrm{II})$ complexes featuring an amine type $\mathrm{N}-\mathrm{C}-\mathrm{N}$ or phosphine type $\mathrm{P}-\mathrm{C}-\mathrm{P}$ "pincer" ligand.

\section{Experimental Section}

General Comments. All reactions involving air-sensitive compounds were carried out under a dinitrogen atmosphere using standard Schlenk techniques. Solvents were dried and

(22) Anderson, C.; Crespo, M.; Font-Bardia, M.; Klein, A.; Solans, X. J . Organomet. Chem. 2000, 601, 22-33.

(23) Doppiu, A.; Agostina Cinellu, M.; Minghetti, G.; Stoccoro, S.; Zucca, A.; Manassero, M.; Sansoni, M. Eur. J. Inorg. Chem. 2000, 2555-2563.

(24) Fang, X.; Scott, B. L.; Watkin, J . G.; Kubas, G. J . Organome tallics 2000, 19, 4193-4195.

(25) Hinman, J . G.; Baar, C. R.; J ennings, M. C.; Puddephatt, R. J Organometallics 2000, 19, 563-570.

(26) Hartley, F. R. In Comprehensive Organometallic Chemistry; Abel, E. W., Stone, F. G. A., Wilkinson, G., Eds.; Pergamon Press: Oxford, U.K., 1982; Vol. 6, p 471.

(27) Anderson, G. K. In Comprehensive Organometallic Chemistry II: A Review of the Literature 1982-1994; Abel, E. W., Stone, F. G. A., Wilkinson, G., Eds.; Pergamon Press: Oxford, U.K., 1995; Vol. 9, p 431.

(28) Terheijden, J .; van Koten, G.; Vinke, I. C.; Spek, A. L. J . Am Chem. Soc. 1985, 107, 2891-2898.

(29) Albrecht, M.; van Koten, G. Angew. Chem., Int. Ed. 2001, 40, 3750-3781.

(30) Albrecht, M.; Spek, A. L.; van Koten, G. J . Am. Chem. Soc. 2001, 123, 7233-7246

(31) Rybtchinski, B.; Milstein, D. Angew. Chem., Int. Ed. 1999, 38, 870-883. distilled prior to use, according to standard methods. ${ }^{32}{ }^{195} \mathrm{Pt}$ NMR spectroscopy was measured via a normal HMQC sequence on a Bruker DRX300 spectrometer at $64.3 \mathrm{MHz}$ at 298 $\mathrm{K}$. Positive chemical shifts $(\delta)$ are denoted for high-frequency shifts relative to a TMS reference $\left({ }^{1} \mathrm{H},{ }^{13} \mathrm{C}\right)$ and an $\mathrm{Na}_{2} \mathrm{PtCl}_{6}$ reference (195Pt). HRMS measurements were performed on a J EOL J MS SX/SX102A four-sector mass spectrometer, coupled to a J EOL MS-MP9021D/UPD system program. For fast atom bombardment ( $F A B)$ mass spectrometry, the samples were loaded in a matrix solution (3-nitrobenzyl alcohol) onto a stainless steel probe and bombarded with xenon atoms with an energy of $3 \mathrm{keV}$. During the high-resolution FAB-MS measurements a resolving power of 10000 (10\% valley definition) was used.

Materials. 2-Bromoisophthalaldehyde ${ }^{33}$ and $\mathrm{Pt}(\mathrm{dipdba})_{2}{ }^{34}$ were prepared according to literature procedures. Molecular sieves ( $3 \AA$ ) were activated by heating at $150{ }^{\circ} \mathrm{C}$ in vacuo overnight. All other starting materials were obtained from commercial sources and used as received.

Bis(N-2,6-di methylphenyl)-2-bromoisophthalaldimine. To a solution of 2-bromoisophthalaldehyde (1.5 g, 7.0 $\mathrm{mmol}$ ) in $50 \mathrm{~mL}$ of toluene was added 2,6-dimethylaniline (2 $\mathrm{mL}, 2.1 \mathrm{~g}, 17.6 \mathrm{mmol}$ ) and $3 \AA$ molecular sieves. The reaction mixture was stirred overnight at $60^{\circ} \mathrm{C}$ and filtered, after which the solvent was evaporated under reduced pressure. The residue was washed with $50 \mathrm{~mL}$ of pentane and dried in vacuo to yield $2.45 \mathrm{~g}(5.8 \mathrm{mmol}, 84 \%)$ of a yellow solid which was identified by ${ }^{1} \mathrm{H}$ and ${ }^{13} \mathrm{C} N M R$ spectroscopy as the pure compound. ${ }^{1} \mathrm{H}$ NMR $\left(500 \mathrm{MHz} \mathrm{CDCl}_{3}\right): \delta 8.75(\mathrm{~s}, 2 \mathrm{H} ; \mathrm{HC}=$ $\mathrm{N}), 8.41\left(\mathrm{~d}, 3_{\mathrm{Hн}}=7.5 \mathrm{~Hz}, 2 \mathrm{H}\right), 7.58\left(\mathrm{t}, 3_{\mathrm{\mu H}}=7.5 \mathrm{~Hz}, 1 \mathrm{H}\right)$, 7.11 (bs, 6H) $, 2.20(\mathrm{~s}, 12 \mathrm{H}) .{ }^{13} \mathrm{C} \mathrm{NMR}\left(126 \mathrm{MHz}, \mathrm{CDCl}_{3}\right): \delta$ $162.1(\mathrm{C}=\mathrm{N}), 151.1(\mathrm{C}), 135.9(\mathrm{C}), 131.7(\mathrm{CH}) 128.7(\mathrm{C}-\mathrm{Br})$, $128.5(\mathrm{CH}), 128.2(\mathrm{CH}), 127.3(\mathrm{C}), 124.4(\mathrm{CH}), 18.7\left(\mathrm{CH}_{3}\right)$. HRMS (FAB): $\mathrm{m} / \mathrm{z}$ calcd $\left([\mathrm{M}+\mathrm{H}]^{+} \mathrm{C}_{24} \mathrm{H}_{24} \mathrm{~N}_{2}{ }^{79} \mathrm{Br}\right) 419.1123$, found 419.1124. Anal. Calcd for $\mathrm{C}_{24} \mathrm{H}_{23} \mathrm{BrN}_{2}$ : C, 68.74; $\mathrm{H}, 5.53$; $\mathrm{N}, 6.68$. Found: $\mathrm{C}, 68.88 \mathrm{H}, 5.48 ; \mathrm{N}, 6.65$.

$\left[\kappa \mathbf{C}, k \mathbf{N}, k \mathbf{N}^{\prime}-\mathbf{B}\right.$ is(N-2,6-dimethylphenyl)isophthalaldimin2-yl]platinum(II) Bromide (1b). To a solution of bis(N-2,6dimethylphenyl)-2-bromoisophthalaldimine (1.0 g, $2.4 \mathrm{mmol})$ in $30 \mathrm{~mL}$ of THF was added Pt(dipdba) 2 (3.5 g, $3.0 \mathrm{mmol}$ ), and the reaction mixture was stirred overnight at $60^{\circ} \mathrm{C}$. ${ }^{1} \mathrm{H}$ NMR spectroscopic analysis showed a partial conversion, and there fore another portion of $\mathrm{Pt}(\mathrm{dipdba})_{2}(1.1 \mathrm{~g}, 1.4 \mathrm{mmol})$ was added. When the reaction was complete, the reaction mixture was cooled to room temperature, upon which the product crystallized. The reaction mixture was filtered over Celite, and the product was extracted from the residue with dichloromethane. The solvent was evaporated under reduced pressure, and the product was dried in vacuo to yield $1.3 \mathrm{~g}(2.1 \mathrm{mmol}, 88 \%)$ of a bright orange solid which was identified by ${ }^{1} \mathrm{H},{ }^{13} \mathrm{C}$, and ${ }^{195} \mathrm{Pt}$ NMR spectroscopy as pure 1b. ${ }^{1} \mathrm{H}$ NMR $\left(300 \mathrm{MHz}^{\left.-\mathrm{CDCl}_{3}\right): \delta}\right.$ $8.44\left(\mathrm{~s}, 3^{3} \mathrm{HPt}=144 \mathrm{~Hz}, 2 \mathrm{H} ; \mathrm{HC}=\mathrm{N}\right), 7.71\left(\mathrm{~d}, 3^{3} \mathrm{\mu H}=7.5 \mathrm{~Hz}\right.$, $2 \mathrm{H}), 7.32\left(\mathrm{t}, 3_{\mathrm{HH}}=7.5 \mathrm{~Hz}, 1 \mathrm{H}\right), 7.10(\mathrm{bs}, 6 \mathrm{H}), 2.27(\mathrm{~s}, 12 \mathrm{H}$; $\left.\mathrm{CH}_{3}\right) \cdot{ }^{13} \mathrm{C} N M R\left(126 \mathrm{MHz} \mathrm{CDCl}_{3}\right): \delta 179.1{ }^{(2 \mathrm{~J}} \mathrm{CPt},=106 \mathrm{~Hz}$, $\mathrm{C}=\mathrm{NC}), 178.4\left(\mathrm{C}-\mathrm{Pt},{ }^{1} \mathrm{~J} \mathrm{CPt}=935 \mathrm{~Hz}\right), 148.1(\mathrm{C}=\mathrm{NC}), 142.1$ (3) $\mathrm{CPt}=116 \mathrm{~Hz}, \mathrm{C}), 131.3(3 \mathrm{JPt}=10 \mathrm{~Hz}, \mathrm{C}), 128.1(\mathrm{CH}), 128.0$ (CH), $127.5(\mathrm{CH}), 123.0(\mathrm{CH}), 18.5\left(\mathrm{CH}_{3}\right) .{ }^{195} \mathrm{Pt} \mathrm{NMR}\left(\mathrm{CDCl}_{3}\right)$ : $\delta-3562$. HRMS (FAB): $\mathrm{m} / \mathrm{z}$ calcd $\left([\mathrm{M}+\mathrm{H}]^{+} \mathrm{C}_{24} \mathrm{H}_{24} \mathrm{~N}_{2}{ }^{79} \mathrm{Br}^{195}\right.$ Pt) 614.0773, found 614.0714.

Methyl [ $\kappa \mathbf{C}, \kappa \mathbf{N}, \kappa \mathbf{N}^{\prime}$-bis(N-2,6-diisopropylphenyl)isophthalaldimin-2-yl]platinum(II) (2a). To a solution of 1a (113 mg, $0.16 \mathrm{mmol}$ ) in $20 \mathrm{~mL}$ of THF was added dimethylzinc ( $2 \mathrm{~mL}$ of a $2.0 \mathrm{M}$ solution in toluene, $4 \mathrm{mmol}$ ). In $10 \mathrm{~min}$ the orange reaction mixture turned red, and the reaction was very gently quenched with water. Most of the THF was evaporated

(32) Perrin, D. D.; Armarego, L. F. Purification of Laboratory Chemicals; Pergamon Press: Oxford, U.K., 1998.

(33) Gelling, O. J .; Feringa, B. L. Recl. Trav. Chim. Pays-Bas 1991, 110, 89-91.

(34) Keasey, A.; Mann, B. E.; Yates, A.; Maitlis, P. M. J . Organomet. Chem. 1978, 152, 117-123. 
under reduced pressure, and the mixture was extracted three times with $30 \mathrm{~mL}$ of pentane. The organic layer was washed subsequently with water and a concentrated $\mathrm{NaHCO}_{3}$ solution and dried on $\mathrm{MgSO}_{4}$. After filtration the solvents were evaporated in vacuo. The residue was extracted with $200 \mathrm{~mL}$ of pentane. The pentane was removed under reduced pressure, and the solid material was washed two times with a small amount of pentane and dried in vacuo to yield $98 \mathrm{mg}(0.15$ $\mathrm{mmol}, 95 \%)$ of an orangered solid which was identified by ${ }^{1} \mathrm{H}$, ${ }^{13} \mathrm{C}$, and ${ }^{195} \mathrm{Pt} \mathrm{NMR}$ spectroscopy as pure $\mathbf{2 a} .{ }^{1} \mathrm{H}$ NMR (300 $\left.\mathrm{MHz}, \mathrm{C}_{6} \mathrm{D}_{6}\right): \delta 8.14\left(\mathrm{~s},{ }^{3} \mathrm{HPt}=125 \mathrm{~Hz}, 2 \mathrm{H} ; \mathrm{HC}=\mathrm{N}\right), 7.42(\mathrm{~d}$, 3) $\left.\mathrm{HH}^{2}=7.5 \mathrm{~Hz}, 2 \mathrm{H}\right), 7.07$ (m, obscured by solvent), 6.92 (t, 3) $\mathrm{HH}$ $=7.5 \mathrm{~Hz}, 1 \mathrm{H}$ ), 3.31 (septet, 3 ${ }_{\mathrm{HH}}=6.8 \mathrm{~Hz}, 4 \mathrm{H} ; \mathrm{CH}_{3} \mathrm{CHCH}_{3}$ ), 1.28 (d, 3 $\left.\mathrm{H}_{\mathrm{H}}=7 \mathrm{~Hz}, 12 \mathrm{H} ; \mathrm{CH}_{3} \mathrm{CHCH}_{3}\right), 0.98$ (d, 3 $\mathrm{HH}_{\mathrm{HH}}=7 \mathrm{~Hz}$, $\left.12 \mathrm{H} ; \mathrm{CH}_{3} \mathrm{CHCH}_{3}\right), 0.67\left(\mathrm{~s},{ }^{3} \mathrm{HPt}=53 \mathrm{~Hz}, \mathrm{Pt}-\mathrm{CH}_{3}\right) .{ }^{13} \mathrm{C} \mathrm{NMR}$ (126 MHz, $\left.{ }_{6} \mathrm{D}_{6}\right): \delta 204.6(\mathrm{C}-\mathrm{Pt}), 180.3{ }^{(2} \mathrm{J} \mathrm{cPt}=56 \mathrm{~Hz}, \mathrm{C}=$ $\mathrm{N}), 146.7$ (C), $143.2\left({ }^{2} \mathrm{~J} \mathrm{CPt}=89 \mathrm{~Hz}, \mathrm{C}\right), 141.4(\mathrm{C}), 127.4(\mathrm{CH})$, $126.6(\mathrm{CH}), 123.1(\mathrm{CH}), 121.7(\mathrm{CH}), 27.6\left(\mathrm{CH}_{3} \mathrm{CHCH}_{3}\right), 24.2$ $\left(\mathrm{CH}_{3} \mathrm{CHCH}_{3}\right), 22.8\left(\mathrm{CH}_{3} \mathrm{CHCH}_{3}\right), 10.2\left({ }^{1} \mathrm{~J} \mathrm{CPt}=623 \mathrm{~Hz}, \mathrm{Pt}-\right.$ $\left.\mathrm{CH}_{3}\right)$. ${ }^{195} \mathrm{Pt} \mathrm{NMR}\left(\mathrm{C}_{6} \mathrm{D}_{6}\right): \delta-3074$. HRMS (FAB): $\mathrm{m} / \mathrm{z}$ calcd $\left([\mathrm{M}+\mathrm{H}]^{+} \mathrm{C}_{33} \mathrm{H}_{43} \mathrm{~N}_{2} \mathrm{Pt}\right) 662.3077$, found 662.3040. Anal. Calcd for $\mathrm{C}_{33} \mathrm{H}_{42} \mathrm{~N}_{2} \mathrm{Pt}$ : C, 59.89; $\mathrm{H}, 6.40 ; \mathrm{N}, 4.23$. Found: C, 60.09; $\mathrm{H}, 6.35 ; \mathrm{N}, 4.17$. Single crystals suitable for $\mathrm{X}$-ray structure determination were obtained by cooling a concentrated toluene solution.

Methyl[ $k \mathbf{C}, k \mathbf{N}, k \mathbf{N}^{\prime}$-bis(N-2,6-dimethylphenyl)isophthalaldimin-2-yl]platinum(II) (2b). Compound $\mathbf{2 b}$ was prepared, in analogy to $\mathbf{2 a}$, from $\mathbf{1 b}(159.1 \mathrm{mg}, 0.259 \mathrm{mmol}$ ) and dimethylzinc ( $2 \mathrm{~mL}$ of a $2.0 \mathrm{M}$ solution in toluene, $4 \mathrm{mmol}$ ). During the workup, hexane was used instead of pentane. The yield was $114 \mathrm{mg}(0.21 \mathrm{mmol}, 80 \%)$ of an orange-red solid which was identified by ${ }^{1} \mathrm{H},{ }^{13} \mathrm{C}$, and ${ }^{195} \mathrm{Pt} \mathrm{NMR}$ spectroscopy as pure $\mathbf{2 b}$. The workup has to be performed quickly, since otherwise an increasing amount of a decomposition product, which is insoluble in hexane, is formed. ${ }^{1} \mathrm{H} N \mathrm{NMR}(300 \mathrm{MHz}$, $\left.\left.\mathrm{C}_{6} \mathrm{D}_{6}\right): \delta 7.63\left(\mathrm{~s},{ }^{3}\right) \mathrm{HPt}=125 \mathrm{~Hz}, 2 \mathrm{H} ; \mathrm{HC}=\mathrm{N}\right), 7.42\left(\mathrm{~d},{ }^{3}\right) \mathrm{HH}=$ $7.5 \mathrm{~Hz}, 2 \mathrm{H}), 6.95\left(\mathrm{t},{ }^{3} \mathrm{Hн}_{\mathrm{H}}=7.5 \mathrm{~Hz}, 1 \mathrm{H}\right), 6.86(\mathrm{br} \mathrm{s}, 6 \mathrm{H}), 2.07$ $(\mathrm{s}, 12 \mathrm{H}), 0.66\left(\mathrm{~s},{ }^{3} \mathrm{JPt}=53 \mathrm{~Hz}, \mathrm{Pt}-\mathrm{CH}_{3}\right) \cdot{ }^{13} \mathrm{C} \mathrm{NMR}(126 \mathrm{MHz}$, $\left.\mathrm{C}_{6} \mathrm{D}_{6}\right): \delta 204.0$ ( $\left.{ }^{1} \mathrm{~J} \mathrm{CPt}=591 \mathrm{~Hz}, \mathrm{C}-\mathrm{Pt}\right), 180.6\left({ }^{2} \mathrm{~J} \mathrm{cPt}=52 \mathrm{~Hz}\right.$, $\mathrm{C}=\mathrm{N}), 149.2,143.4\left({ }^{2} \mathrm{~J} \mathrm{cPt}=91 \mathrm{~Hz}\right), 131.1,129.3,126.6,126.5$, 121.6, $18.4\left(\mathrm{Ar}-\mathrm{CH}_{3}\right), 8.7\left({ }^{1} \mathrm{~J} \mathrm{CPt}=604 \mathrm{~Hz}, \mathrm{Pt}-\mathrm{CH}_{3}\right) .{ }^{195} \mathrm{Pt} \mathrm{NMR}$ $\left(\mathrm{C}_{6} \mathrm{D}_{6}\right): \delta$-3096. HRMS (FAB): $\mathrm{m} / \mathrm{z}$ calcd $\left(\left[\mathrm{M}-\mathrm{CH}_{3}\right]^{+}\right.$ $\mathrm{C}_{24} \mathrm{H}_{23} \mathrm{~N}_{2} \mathrm{Pt}$ ) 535.1590, found 535.1579.

Crystal Data for 2a: $\mathrm{C}_{33} \mathrm{H}_{42} \mathrm{~N}_{2} \mathrm{Pt}$, fw $=661.78$, red block, $0.18 \times 0.10 \times 0.09 \mathrm{~mm}^{3}$, orthorhombic, $\mathrm{P} 22_{1} 2_{1} 2_{1}$ (No. 19), $\mathrm{a}=$
11.2859(1) $\AA, b=14.6377(1) \AA, c=17.7437(1) \AA, V=2931.25$ (4) $\AA^{3}, Z=4, D_{x}=1.500 \mathrm{~g} / \mathrm{cm}^{3}, \mu=4.810 \mathrm{~mm}^{-1}$. A total of 34018 reflections were measured on a Nonius KappaCCD diffractometer with rotating anode $(\lambda=0.71073 \AA)$ at a temperature of $150(2) \mathrm{K}$ up to a resolution of $((\sin \theta) / \lambda)_{\max }=$ $0.65 \AA^{-1} ; 6705$ reflections were unique $\left(R_{\text {int }}=0.036\right)$. An analytical absorption correction was applied $(0.47-0.72$ transmission). The structure was solved with automated Patterson methods (DIRDI F-97) 35 and refined with SHELXL-9736 against $\mathrm{F}^{2}$ values of all reflections. N on-hydrogen atoms were refined freely with anisotropic displacement parameters. $\mathrm{H}$ atoms of the imine group were refined freely with isotropic displacement parameters; all other $\mathrm{H}$ atoms were refined as rigid groups (334 refined parameters, no restraints). $\mathrm{R}$ values $(I>2 \sigma(I))$ : $\mathrm{R} 1=0.0153, \mathrm{wR} 2=0.0359$. $\mathrm{R}$ values (all reflections): $\mathrm{R} 1=$ $0.0158, w R 2=0.0361$. The Flack $x$ parameter $^{37}$ is $-0.016(4)$, the GOF value is 1.050, and the residual electron density is between -0.67 and $0.57 \mathrm{e} / \AA^{3}$. Molecular illustration, structure checking and calculations were performed with the PLATON package. $^{38}$

Acknowledgment. This work was supported in part (W.J .H., A.L.S., M.L.) by The Netherlands Foundation for Chemical Sciences (CW) with financial aid from The Netherlands Organization for Scientific Research (NWO).

Supporting Information Available: X-ray CIF file for 2a. This material is available free of charge via the Internet at http://pubs.acs.org. CCDC 215854 contains the supplementary crystallographic data for this paper. These data can be obtained free of charge via www.ccdc.cam.ac.uk/conts/retrieving.html (or from the CCDC, 12 Union Road, Cambridge CB2 IEZ, U.K.; fax +44 1223 336033; e-mail deposit@ccdc.cam. ac.uk).

OM0343972

(35) Beurskens, P. T.; Admiraal, G.; Beurskens, G.; Bosman, W. P.; Garcia-Granda, S.; Gould, R. O.; Smits, J . M. M.; Smykalla, C. DIRDIF97: University of Nijmegen, Nijmegen, The Netherlands, 1997.

(36) Sheldrick, G. M. SHELXL-97; U niversity of Göttingen, Göttingen, Germany, 1997.

(37) Flack, H. D. Acta Crystallogr. 1983, A39, 876-881.

(38) Spek, A. L. J . Appl. Crystallogr. 2003, 36, 7-13. 